\title{
Piedad y suntuosidad: los ornamentos litúrgicos de tres colecciones limeñas
}

\author{
Emma Patricia Victorio Cánovas \\ Universidad Nacional Mayor de San Marcos, Perú ${ }^{1}$
}

La grandeza de Dios, reflejada en los ornamentos litúrgicos y en los elementos que rodean el culto, encontró en el arte del bordado el medio apropiado para manifestarse. Espiritualidad, arte y tradición forjaron en el Virreinato del Perú una de sus más notables expresiones gracias a las hábiles manos de bordadores andinos y españoles. La variedad de telas y los hilos entorchados de oro, plata y de seda de colores se transformaron en sus manos en auténticas "pinturas", los motivos sagrados cubrieron las piezas casi en su totalidad, el color, el preciosismo y el detalle caracterizaron al conjunto.

Los ornamentos litúrgicos no sólo ostentan contenidos impulsados por la iglesia, sino que integran valores plásticos de origen local. Cada una de las prendas constituye una manifestación del arte sacro y es portadora de una gran carga simbólica, que se expresa mediante una iconografía que se adecúa a la normativa eclesiástica establecida por el Concilio de Trento. Aunque estas vestiduras no fueron creadas con el propósito del deleite estético, son indiscutibles obras de arte por el resultado excepcional de su factura, la prolija y puntual organización de los elementos ornamentales que componen las piezas, y la impresión que se buscó lograr en el receptor. Se trata de significativas obras de arte textil, en las que intervienen tres de sus principales manifestaciones: el tejido,

\footnotetext{
${ }^{1}$ Facultad de Letras y Ciencias Humanas, Departamento Académico de Arte.
} 
el bordado y el vestido. Sin embargo, a pesar del virtuosismo en su elaboración - que revela una gran capacidad artística y creativa-, así como la riqueza de materiales con las que han sido confeccionadas, los temas decorativos que exhiben, y las implicancias sociales y económicas de su producción, estas obras no han suscitado el interés de los investigadores, para quienes se trata de una expresión de las artes menores.

También, conviene recordar que cada una de las prendas constituye un todo unitario, una manifestación del arte sacro poseedora de una gran carga simbólica, que se expresa mediante una iconografía relacionada con el ceremonial y de acuerdo con la normativa eclesiástica establecida por el Concilio de Trento, respecto al ornato y al decoro. Por otro lado, el programa iconográfico, presente en los ornamentos litúrgicos, transmite conceptos propios de la Iglesia al grupo de fieles que participa de la celebración, a la vez que refuerza su religiosidad. Se desarrolla en cada prenda mediante la distribución ordenada de motivos, tomados del repertorio cristiano o adaptados del mundo clásico, articulados en el contexto de la fe en un discurso en el que destaca tanto la coherencia interna, como su relación con el color. Ningún elemento está colocado al azar o fuera de lugar, logrando un equilibrio entre forma, función y mensaje.

El artículo tiene como propósito contribuir al conocimiento de los ornamentos litúrgicos en general y a su reconocimiento como obras de arte a partir del análisis de la selección de una casulla representativa de las colecciones de la Basílica Catedral de Lima, del Convento de San Francisco y del Monasterio de Nazarenas Carmelitas Descalzas. Estas prendas, aunque han permanecido inéditas y han sido escasamente apreciadas por la gran mayoría, reflejan las prácticas cristianas desarrolladas durante los periodos virreinal y republicano y forman parte del patrimonio cultural de la nación.

La mayoría de los ornamentos litúrgicos se retiró del uso diario como resultado de los cambios decretados por el Concilio Vaticano II, ${ }^{2}$ que acordó que las prendas revelaban carácter sagrado por sí mismas y no por su adorno, permitió que se continúe su confección en telas y materiales preciosos, pero recomendó una ornamentación discreta que, en muchos casos, podía formar parte del mismo tejido. Por otro lado, el estudio de los ornamentos litúrgicos es una tarea ardua debido a que

... son pocas las piezas que se han conservado intactas, era frecuente aprovechar cenefas de prendas deterioradas para piezas nuevas o hacer restauraciones que en el mejor de los casos pasan desapercibidas. En consecuencia, es difícil asociar la documentación a una pieza determinada, casi nunca se dan indicaciones suficientes sobre las imágenes que ha de llevar la cenefa ni sobre la pieza en la que ha de ir colocada y cuando

\footnotetext{
${ }^{2}$ El Concilio Vaticano II se realizó entre los años 1962 y 1965.
} 
ésto [sic] se hace, el problema consiste en averiguar de qué pieza se trata ya que, como en casi todas las artes industriales, los modelos y los procesos técnicos se repiten durante muchos años sin variaciones apreciables. Teniendo en cuenta que son pocos los nombres de bordadores conocidos y menos las piezas que se les pueden atribuir con absoluta certeza, es arduo encontrar peculiaridades técnicas o estilísticas que permitan atribuciones fiables o dataciones precisas. ${ }^{3}$

La propia Iglesia ha contribuido a la pérdida irreparable de los ornamentos litúrgicos, a pesar que incentivó labores encaminadas al remozamiento de las piezas con el objetivo de preservarlas, muchas veces esas intervenciones no han sido apropiadas. Así por ejemplo, a lo largo del tiempo, se intentó reparar los tejidos que servían de soporte a los ornamentos colocando injertos o parches en áreas dañadas, remendando zonas rasgadas o sustituyendo las diversas telas; lo mismo sucedía con los cordones y borlas, y se agregaron o reemplazaron los bordados. Las intervenciones - de las que no queda constancia escrita- ${ }^{4}$ fueron realizadas por los maestros bordadores y los sastres, quienes fueron contratados para ello, y se justificaba su intervención por la presencia de diversos tipos de deterioro en los ornamentos. Finalmente, y aunque se trate de prendas consagradas para su uso, cuando están muy deterioradas y dejan de ser aptas para el culto divino, pierden la bendición y se recomienda que sean quemadas para evitar su profanación.

En algunas zonas del territorio peruano, este hábito se practica hasta la actualidad por la misma razón. Sin embargo, la motivación puede ser también el interés en recuperar el oro o la plata de sus bordados luego de reducir la prenda a cenizas, como sucedía en la Europa medieval. Staniland refiere que, durante el siglo XIV, la razón por la que muchas prendas existentes en la Catedral de Canterbury fueron reducidas a cenizas se debió al interés en recuperar el oro de sus bordados, pues se trataba de un sistema práctico y económico. ${ }^{5}$

\section{SOBRE LOS ORNAMENTOS LITÚRGICOS}

El arte sagrado es aquel cuyas formas reflejan la visión espiritual propia de una religión, y se refiere a las formas y significados que el hombre da a esas formas. En ese sentido, la vestimenta litúrgica sacerdotal cristiana es una expresión del arte sacro, y se refiere al conjunto de prendas indispensables con las cuales los

\footnotetext{
3 Romero Ortega 1989: 107-108.

${ }^{4}$ No hay registros escritos o informes respecto a la manera como dichas intervenciones fueron realizadas.

5 Staniland 2000: 65.
} 
ministros se revisten para la celebración de ritos, ceremonias y, de manera especial, para la solemnidad de la misa. ${ }^{6}$

El conjunto de ornamentos litúrgicos tiene su origen en el antiguo traje civil greco-romano, de uso común hasta fines del siglo VI cuando se generalizó el modo de vestir bárbaro, desde entonces quedó reservado para el culto y su gradual desarrollo se vincula a las adaptaciones relacionadas con su función, la selección de las telas y la incorporación de elementos ornamentales de carácter simbólico. Por sus características, esta indumentaria confiere legitimidad a los ministros y a la función que realizan; asimismo, distingue al clero, marca su jerarquía y, aunque no tiene un valor sagrado en sí misma, cumple varias funciones importantes, ya que recuerda a los fieles que quien se reviste con ella actúa, en ese momento, como Ministro de Cristo, subraya el carácter festivo y contribuye al decoro de la celebración porque "así conviene para su mayor resplandor, hermosura, devoción y reverencia".

Antes del Concilio Vaticano II, el conjunto de ornamentos litúrgicos usado por los miembros de los tres órdenes mayores (sacerdote o ministro, diácono y subdiácono), para celebración de las misas solemnes, se conocía con el nombre de "terno" y estaba compuesto por una casulla, dos dalmáticas, capa pluvial, velo o paño humeral, tres estolas, dos manípulos, bolsa de corporales y un velo de cáliz, que debían ser confeccionados de la misma tela y tener los mismos bordados.

En la celebración de la Eucaristía, las cuatro prendas fundamentales que el ministro lleva son la casulla y la estola así como el alba y cíngulo que la sujeta. El sacerdote usa la casulla sobre el alba y la estola. Esta prenda se caracteriza por no tener costura a los lados y presentar una abertura central para pasar la cabeza, de tal modo que queda una mitad sobre la espalda y la otra sobre el pecho. Es el vestido principal de la liturgia católica por su función, simbolismo y estética. ${ }^{8}$ Para su confección se han empleado las telas más finas, especialmente de seda y sobre las suntuosas telas se realizaba el bordado. Por

${ }^{6}$ El capítulo I del Misal Romano señala que la celebración de "La Misa, como acción de Cristo y del pueblo de Dios, ordenado jerárquicamente, es el centro de toda la vida cristiana para la Iglesia universal y local, y para todos los fieles individualmente, ya que en ella se culmina la acción con que Dios santifica en Cristo al mundo, y el culto que los hombres tributan al Padre, adorándolo por medio de Cristo, Hijo de Dios...Y puesto que la celebración eucarística, como toda Liturgia, se realiza por signos sensibles, con los que la fe se alimente, se robustece y se expresa, se debe poner todo el esmero posible para que sean seleccionadas y ordenadas las formas y elementos que la Iglesia propone, que, según las circunstancias de personas y lugares, favorezcan más directamente a la activa y plena participación de los fieles, y respondan mejor a su aprovechamiento espiritual" (Misal Romano. Capítulo I. Importancia y dignidad de la Celebración).

${ }^{7}$ Lobera y ABio 1846: 64.

${ }^{8}$ Plazaola 1965: 480 
lo general, una cenefa vertical que recibe el nombre de "columna" la recorre en su parte central, está flanqueada por dos galones llamados "clavi" y concentra la decoración [fig. 1]. La espalda es la zona más importante y vistosa de la casulla, en tanto que los sacerdotes tradicionalmente oficiaban la ceremonia litúrgica de espaldas a la asamblea, es decir, mirando en la misma dirección que el pueblo, hacia el retablo mayor, adosado al ábside.

Fig.1. Casulla de terciopelo. Sección delantera. Confeccionada en terciopelo de seda. Bordado de realce con hilos dorados y plateados. (fot. Archivo del Monasterio de Nazarenas Carmelitas Descalzas)

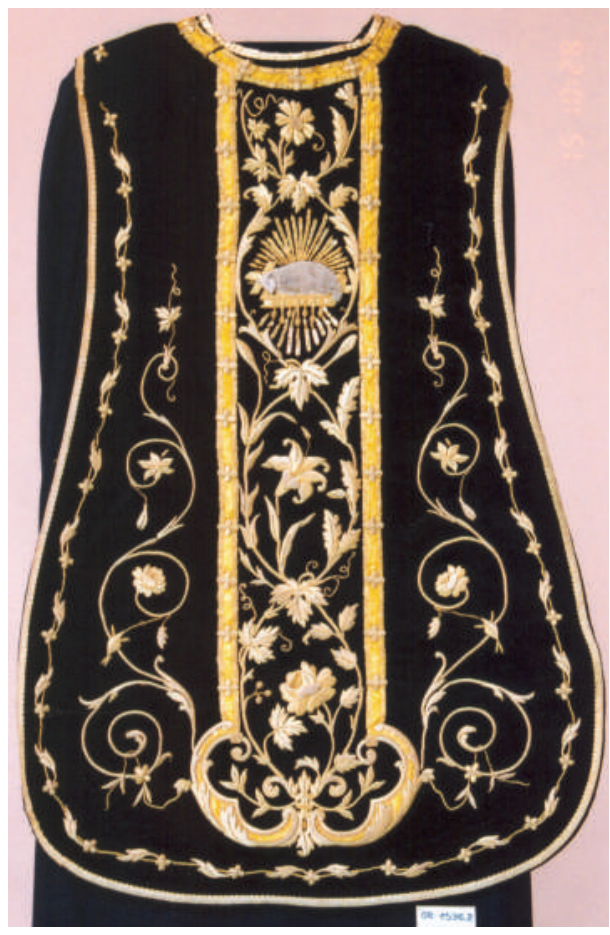

La estola, insignia mayor, es la prenda que debe ser llevada sin excepción por los ministros -ordenados - durante el sacrificio de la misa y otros actos litúrgicos. Presenta una cruz en el centro y puede estar acompañada por otras dos en los extremos. También debe usarse cada vez que el sacerdote tenga contacto con la Eucaristía, para administrar los sacramentos, así como para bendecir a las personas y cosas. El alba es un vestido interior de color blanco, a manera de túnica larga y sencilla, común a todos los ministros, por lo general presenta encajes tanto en el ruedo como en los puños, y se ciñe a la cintura con un cordón que se denomina cíngulo. Por su color se considera símbolo de la pureza del celebrante. ${ }^{9}$ El cíngulo cumple una función práctica, pues evita que el alba se arrastre y facilita los movimientos del que la lleva. Por recomendación de la Iglesia debe ser de lino, normalmente es de color blanco, pero se admite el uso de otro color, siempre que sea el que corresponde al día en el calendario litúrgico. Sobre la sotana, ${ }^{10}$ traje diario de los eclesiásticos, el ministro se reviste con

\section{RÉAU 2000: 278}

${ }^{10}$ La sotana es una especie de túnica talar de mangas largas, su nombre viene del latín subtana que significa "debajo", su uso fue instituido por la Iglesia a fines del siglo V con el propósito de dar a los sacerdotes un modo de vestir serio, simple y austero. 
los ornamentos sagrados correspondientes a su jerarquía de acuerdo al orden prescrito por la Iglesia.

\section{Telas y Materiales}

La vestimenta sagrada ha sido confeccionada con los materiales más finos y lujosos. Fue luego del Concilio de Trento (1545-1563) cuando la liturgia cobró mayor importancia, y se estimó que el esplendor de los ornamentos debía reflejar, en los oficiantes y en todo lo que rodeaba el culto, la solemnidad del ceremonial. Por su brillo, textura, suavidad al tacto y delicadeza se prefirió el empleo de telas de seda para el exterior, y podían ser de un color, incluir hilos de oro, presentar diversas texturas o integrar motivos de contenido simbólico. La importancia de esta selección se desprende de las cualidades inherentes al material y su resistencia, además de ser un producto muy costoso debido a las dificultades en la obtención de la fibra y la minuciosidad exigida en el telar para la elaboración del tejido, pero también se relaciona con la procedencia de las telas y sus características estructurales, o ligamentos.

Las telas de seda más comunes son:

- Tafetán: es una estructura textil de ligamento sencillo, se caracteriza por el cruce de una trama por una urdimbre de tal modo que quede balanceado, también se conoce como tejido plano [fig. 2].

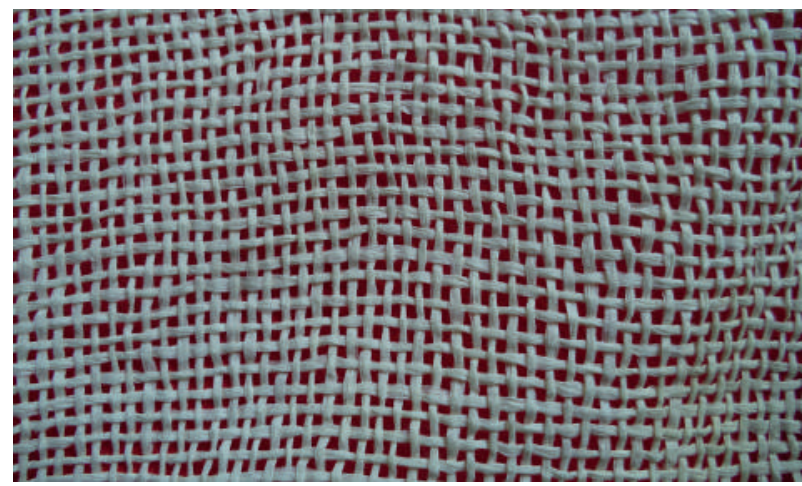

Fig. 2. Tafetán (fot. Patricia Victorio)

- Brocado: es una tela que presenta un conjunto suplementario de tramas que permite la formación de los motivos decorativos que se realizan en el momento de tejer, este conjunto suplementario queda flotante por el revés. 
Puede combinar hilos de seda y de oro o de plata, o de seda y de los dos metales a la vez.

- Lamé: presenta también el cruce de una trama por una urdimbre, pero incluye hilos de oro o plata en la estructura (urdimbre o trama) que solo se aprecian por el anverso [fig. 3].

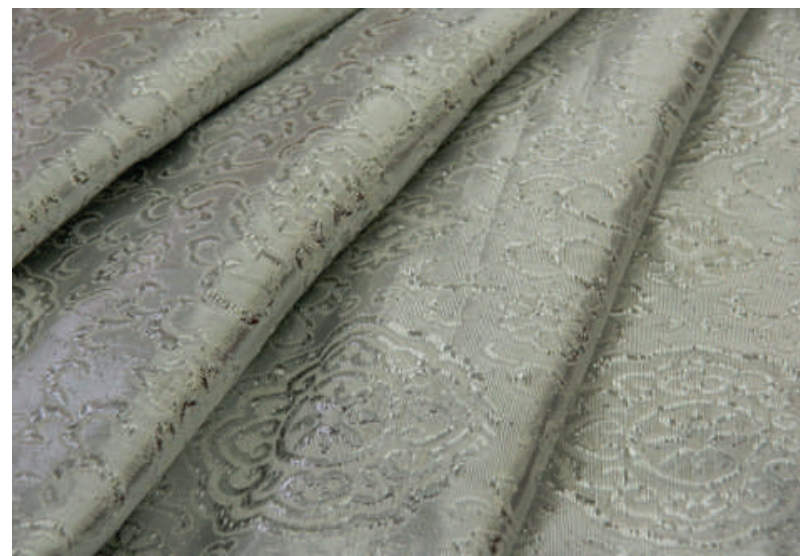

Fig. 3. Lamé de seda y plata (fot. Patricia Victorio)

- Raso: se varía la secuencia en el cruce de los hilos de trama y urdimbre y se forman diagonales como sucede en la sarga, la superficie queda lisa y el anverso brillante, mientras que el reverso es mate [fig. 4].

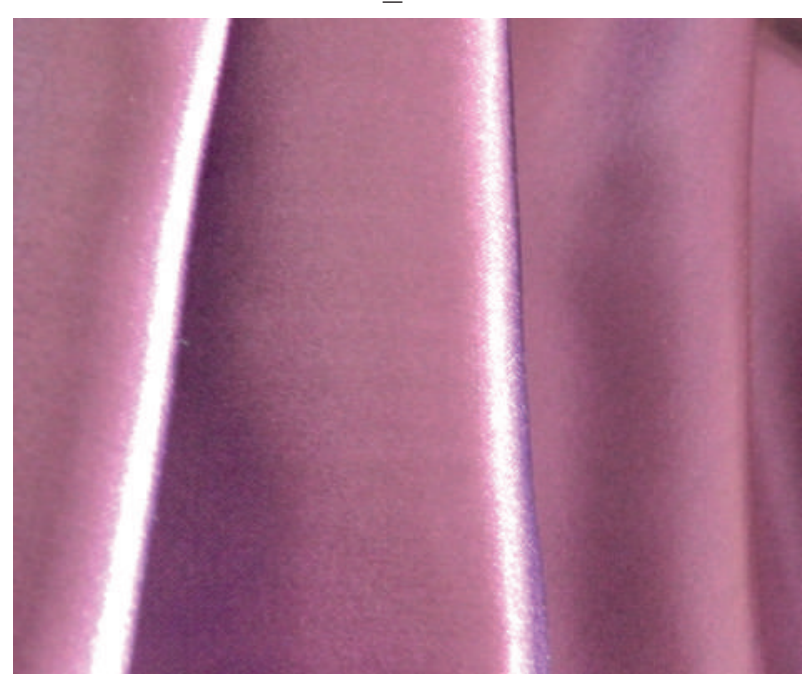

Fig. 4. Raso de seda actual (fot. Patricia Victorio) 
- Damasco: también varía la secuencia de cruce de hilos, pero a diferencia del anterior, forma diseños que se perciben por el contraste entre áreas brillantes y mates, las dos caras presentan el mismo motivo, pero el contraste entre áreas está invertido [fig. 5].
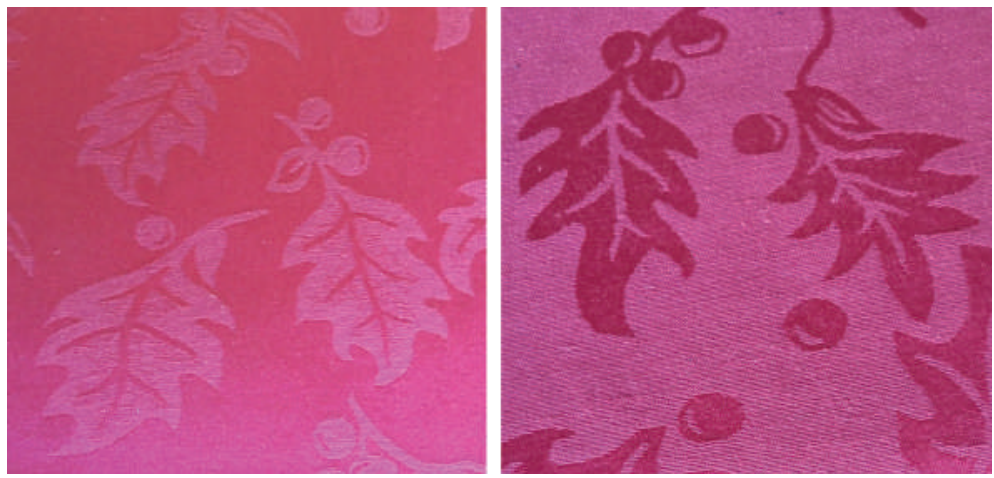

Fig. 5. Damasco de algodón actual: anverso, reverso (fot. Patricia Victorio)

- Terciopelo: presenta una superficie velluda y suave al tacto formada por una trama adicional que forma pequeños anillos en el cruce de tramas y urdimbres, los anillos son cortados cuando el tejido está terminado [fig. 6].

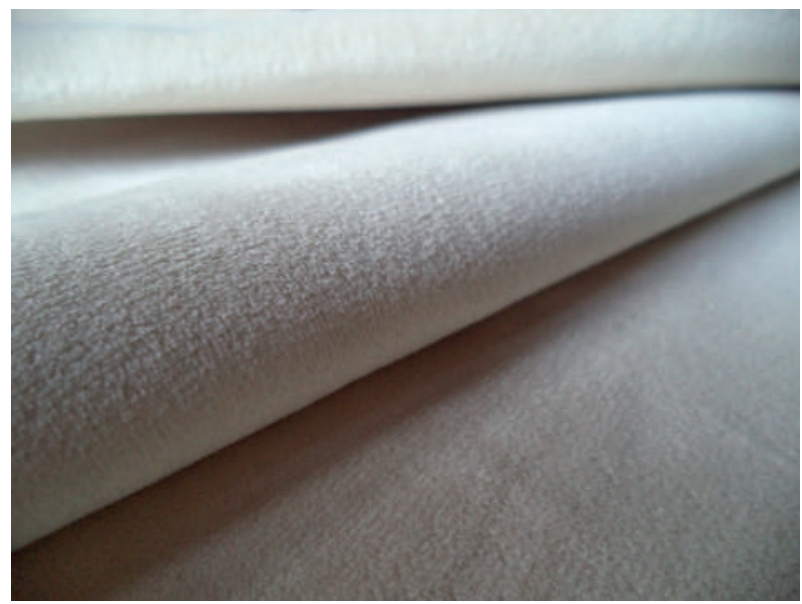

Fig. 6. Terciopelo actual (fot. Patricia Victorio)

- Muaré: no es una estructura textil, es más bien el acabado de la superficie de la tela, en la que mediante presión ejercida con rodillos se genera un efecto de ondas [fig. 7]. 


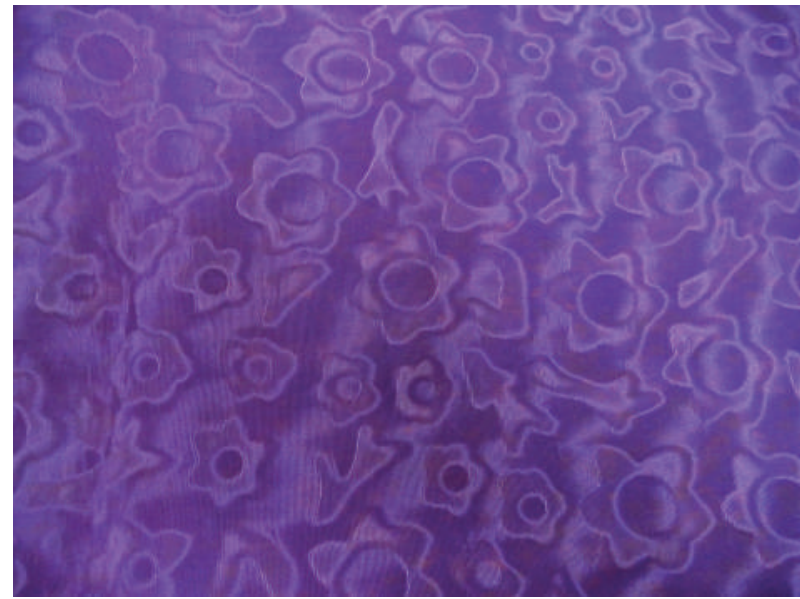

Fig. 7. Muaré de seda actual (fot. Patricia Victorio)

En la confección de los ornamentos litúrgicos participan al menos tres capas de tela de diferente calidad y se remata con el galón en el contorno. Cada una de ellas cumple una función determinada (tela principal, entretela y forro), están recortadas de acuerdo al patrón o molde y van dispuestas como se aprecia en la figura 8 [fig. 8].

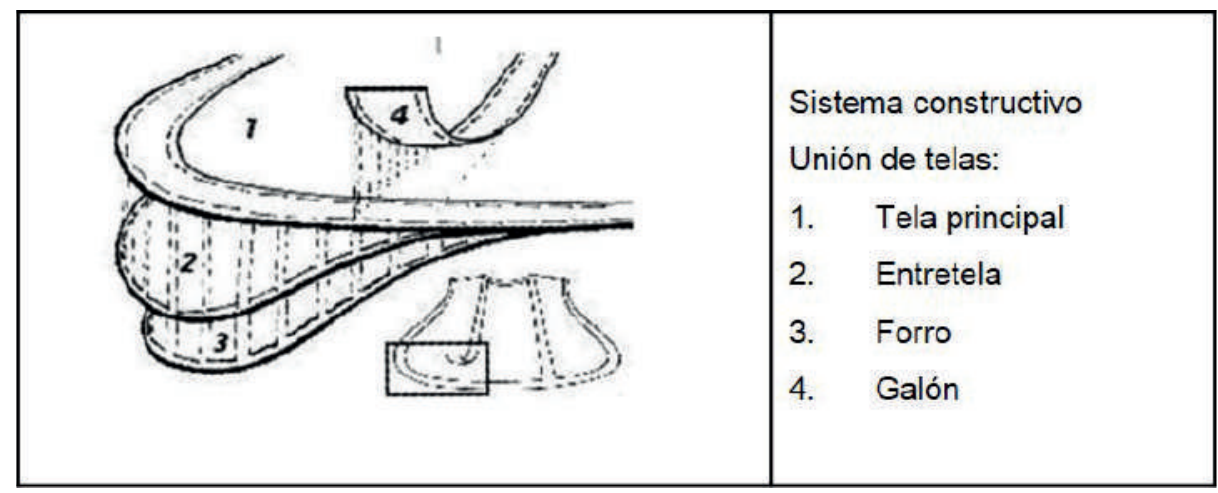

Fig. 8. Esquema constructivo de los componentes de un ornamento (Adaptado de: CLAVIJO et al 2000: 25)

La tela principal (1) es la más fina y queda a la vista, generalmente de seda o de seda y oro, puede ser: brocado, damasco, lamé, muaré, raso o satén, terciopelo, entre otras. Las labores de bordado se realizan sobre ella. La entretela (2) es la capa central, sirve para dar rigidez a la prenda, generalmente es de lino, al que se le aplicaba apresto o una base de preparación con cola diluida [fig. 9], 
para limitar la flexibilidad propia de la seda. Puede presentar estructura de tafetán o de sarga. El forro (3) cubre el revés de la prenda, puede ser de seda o de lino, y algunas veces de algodón, aunque este último no era recomendado. Generalmente, presenta estructura de tafetán. El galón (4) es una cinta o ribete tejido, de seda y oro, que se coloca en todo el perímetro de la prenda a modo de remate.

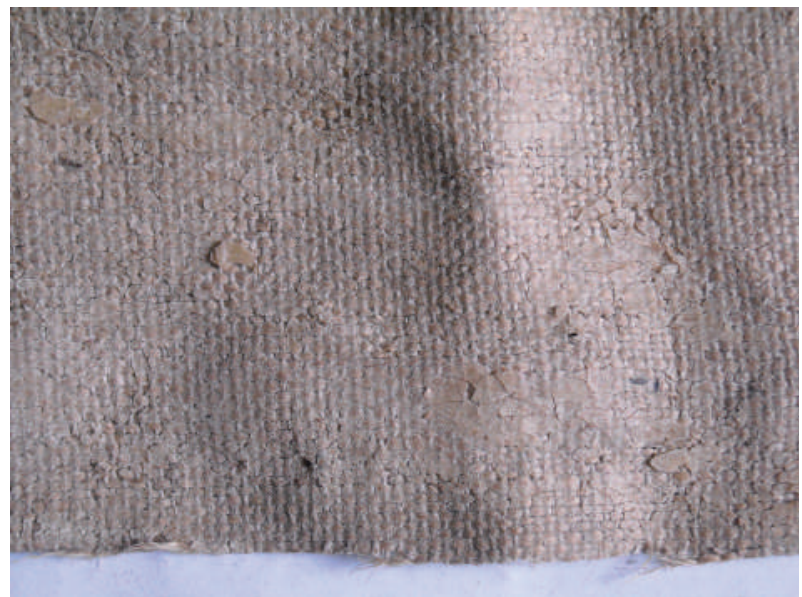

Fig. 9. Entretela de lino con base de preparación. Casulla del siglo XVII-XVIII, detalle. Colección particular (fot. Patricia Victorio)

\section{Tipología Decorativa}

Además de la normativa establecida por la Iglesia y la tradición en cuanto a la forma y los colores que debe conservar la vestimenta litúrgica, y en especial las casullas, hay dos rasgos específicos determinados por la combinación de los factores materiales con los que se confeccionan: el primero de ellos se refiere al tipo de tela de soporte y, el segundo, a la decoración que ostentan. De acuerdo con estos rasgos distintivos, los ornamentos se pueden organizar en dos grandes grupos.

Ornamentos litúrgicos sin motivos decorativos:

Son los más sencillos pues se trata de aquellas prendas confeccionadas con tela de un color - puede ser terciopelo, raso de seda, lamé entre otras - que presentan galones o remates en el contorno, pero carecen de decorado. Las variantes están referidas a la combinación de dos tipos de estructuras textiles en la misma pieza, por ejemplo: una casulla de raso de seda con la columna de terciopelo. 
Ornamentos litúrgicos con motivos decorativos:

Se refiere a las prendas que presentan motivos decorativos que pueden ser tanto estructurales como superestructurales. En este grupo existen al menos cuatro tipos claramente diferenciados. El primero concentra los ornamentos cuyos motivos decorativos son los que poseen las telas con las que se han confeccionado, y van rematados por galones o flecos, incluye: la indumentaria que presenta motivos estructurales propios de la tela de soporte como el damasco o el brocado de seda; y la indumentaria que combina dos telas, una que sirve de soporte y es generalmente de un color, y la otra que presenta motivos decorativos y puede formar la columna en la casulla o el aurifrisium en la capa pluvial.

En el segundo, se encuentran los ornamentos que presentan decoración superestructural, es decir, bordada; están confeccionados con tela de un solo color y presentan galones, remates o flecos en el contorno. Entre ellos se cuentan: los que tienen motivos bordados de acuerdo a un patrón que se repite, de manera ordenada, en toda la superficie de la prenda; un segundo tipo corresponde a aquellos que ostentan bordados, de grandes dimensiones, en una zona específica como la columna en el caso de las casullas.

Un tercer tipo de ornamentos combina la decoración estructural y la superestructural, pues las prendas están confeccionadas con telas que presentan motivos estructurales de grandes dimensiones cuyos contornos están remarcados mediante bordados, generalmente hechos con hilos entorchados, cordoncillos y la aplicación de lentejuelas.

Finalmente, el último tipo es el más interesante y constituye el tema central de la investigación, se refiere a aquellos ornamentos litúrgicos que presentan bordados que desarrollan un discurso iconográfico complejo. La variedad de telas sirvió como la superficie apropiada para estas labores que solo fueron aplicadas a la indumentaria reservada para las celebraciones solemnes.

\section{EL BORDADO}

El bordado es una técnica decorativa, superestructural, que existe desde épocas legendarias. Se realiza puntada a puntada mediante el uso de una aguja e hilos de diversas características - de seda o entorchados ${ }^{11}$ de plata o de oro [fig. 10]-, sobre una superficie plana o soporte, por lo general textil. Las labores también pueden incorporar gemas de colores, lentejuelas y otros adornos.

${ }^{11}$ El hilo entorchado está compuesto por una lámina de metal que envuelve un "alma" de seda, lino, algodón u otro material, y toma la apariencia de un hilo metálico, macizo y flexible. 


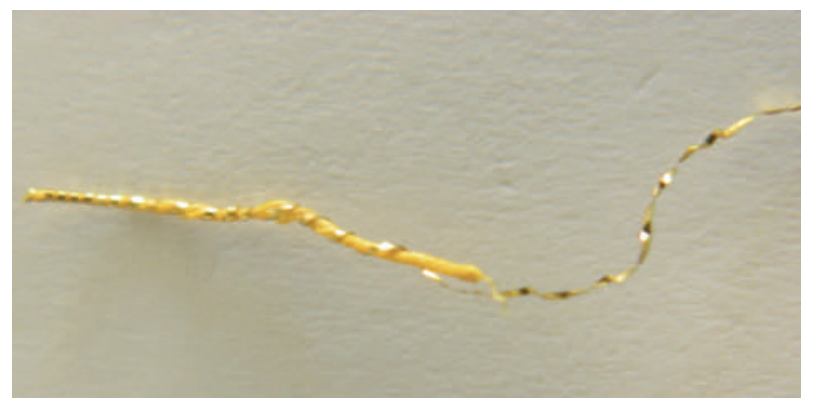

Fig. 10. Vista ampliada de un hilo entorchado de oro laminar con estructura de seda (fot. Marcela Ramírez)

Por sus características de elaboración, el bordado se clasifica en dos grandes grupos:

a) El bordado doméstico o popular, que persiste en el tiempo. Se trata de la labor casera común, que sirve para decorar tanto la vestimenta de uso cotidiano, como el ajuar para el hogar (manteles, sábanas, etc.), y se caracteriza por ser ejecutado sobre una la tela contando los hilos de la trama y la urdimbre. El modelo que se sigue tiene como base una cuadrícula.

b) El bordado erudito, llamado también litúrgico por ser el favorito de la Iglesia y las cofradías. A diferencia del anterior, requiere de un dibujo sobre el soporte, pues no sigue la dirección de la trama y la urdimbre. Es más libre y permite mayor variedad de motivos. Además, "en su elaboración intervienen siempre materiales nobles, tanto en los tejidos de confección de las prendas a bordar, como en los hilos -o en las labores de ornamentación que cubren la superficie textil". ${ }^{12}$

Las técnicas de bordado erudito a su vez se subdividen en dos grandes grupos:

a) El bordado matizado, bordado al matiz o "pintura a la aguja": consiste en bordar sólo con hilos de seda de colores sobre la superficie tejida. En las figuras se mezclan los matices de seda llegando a producir un efecto muy parecido al que da el empaste de los colores aplicados con el pincel [fig. 11], pues "las sedas van marcando las escalas cromáticas, las luces y las sombras, con la misma perfección que se conseguiría mezclando sus colores en una paleta antes de aplicarlos sobre el fondo". ${ }^{13}$ En esta técnica las puntadas atraviesen la tela de soporte, por lo tanto, se ve la labor por el anverso y reverso.

12 Sigüenza Pelarda 2006: 200.

13 Floriano Cumbreño 1942: 152. 


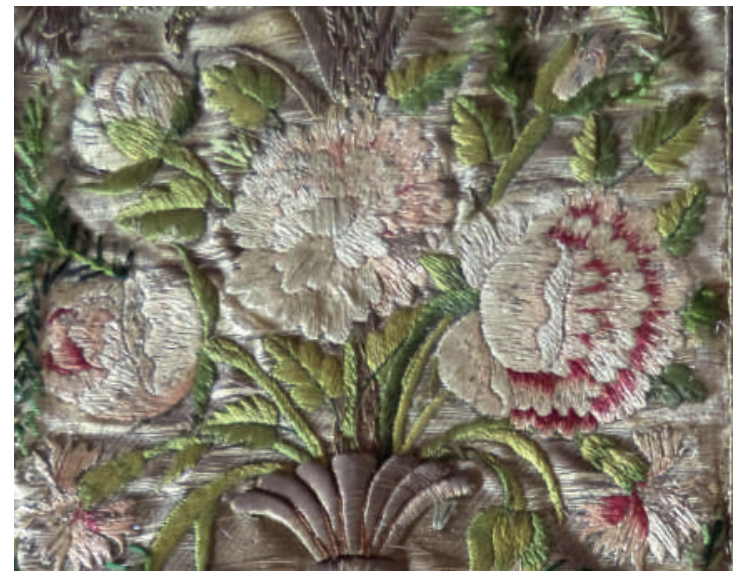

Fig. 11. Matizado o Pintura a la aguja con hilos de seda de colores. Casulla Mariana. Siglo XIX. Detalle. Convento de San Francisco (fot. Patricia Victorio)

b) Bordado "lumínico": es realizado con hilos entorchados los cuales, debido a sus características, no atraviesan la tela de soporte. El bordado lumínico toma su denominación debido tanto a su técnica de ejecución, como a su aspecto. Destacan: el bordado de oro matizado también llamado "a hilo tendido" donde los hilos entorchados se colocan en sentido horizontal sobre el tejido, se fijan con pequeñas puntadas hechas con hilos de seda de colores y el motivo queda plano; el bordado de realce [fig. 12] o de relieve, en el cual los hilos entorchados se enrollan sobre un soporte rígido - de pergamino o cartón - que tiene la forma deseada y luego se fija a la tela con puntadas alrededor; y el bordado de alto relieve, realizado sobre telas que se recortan de acuerdo con los diseños requeridos, luego se introduce un relleno - algodón, lana u otro material - a fin de darles volumen. En la mayoría de los casos, como remate del motivo, se realiza el delineado mediante la colocación alrededor de un cordón de seda o entorchado.

Fig. 12. Bordado de realce con hilos de oro. Casulla morada de muaré de seda. Mediados del siglo XX. Detalle. Monasterio de Nazarenas Carmelitas Descalzas (fot. Patricia Victorio)

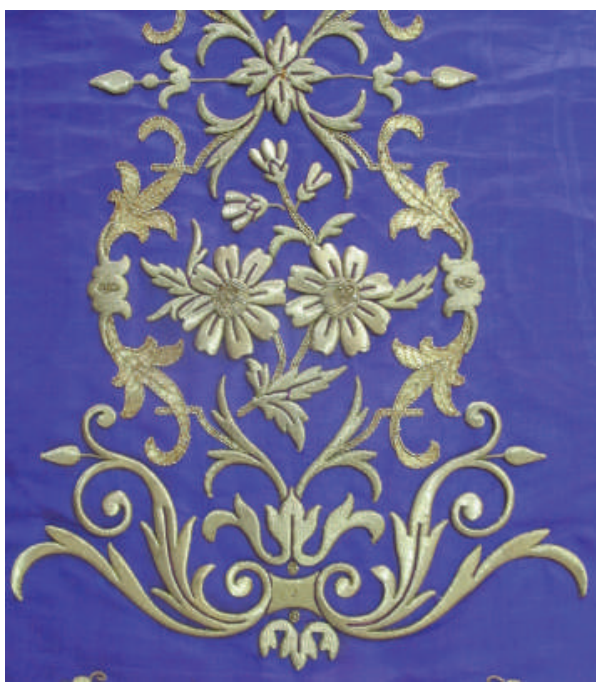


Por lo general, las prendas están cubiertas con abundantes motivos ejecutados en diversas técnicas de bordado para lograr el mayor efecto decorativo [fig. 13].

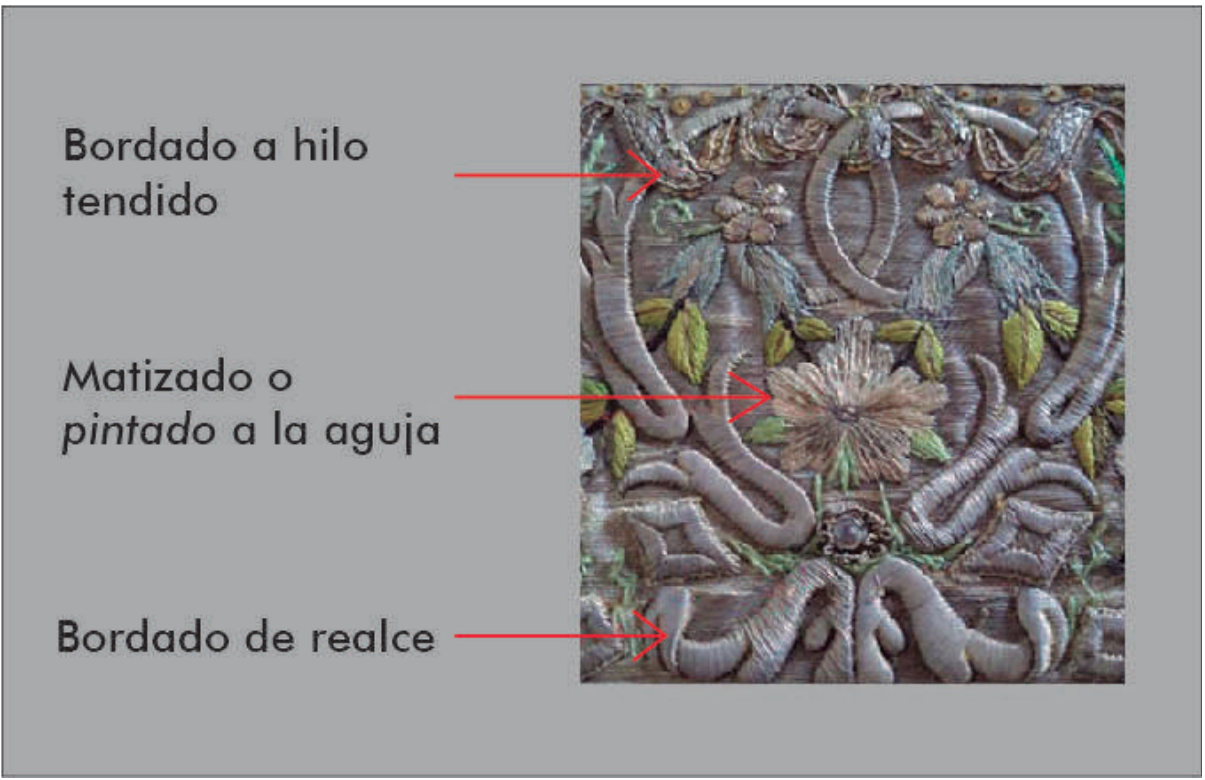

Fig. 13. Diversos tipos de bordado combinados para lograr el efecto deseado. Casulla Mariana. Siglo XIX. Detalle. Convento de San Francisco (fot. Patricia Victorio)

Al mismo tiempo, es necesario añadir que existe una práctica que se ha mantenido a través del tiempo y que se emplea tradicionalmente con la finalidad de recuperar los bordados de las prendas que se encuentran deterioradas por el uso continuo ${ }^{14}$, se trata de la técnica del pasado ${ }^{15}$. Simultáneamente, el pasado ha contribuido al menoscabo de la información respecto a los ornamentos litúrgicos, debido a la eliminación de las telas de soporte, entretelas y forros originales, perdiéndose tanto los datos respecto a las calidades y texturas de las mismas, como las marcas y sellos que pudieran haber tenido. Además, no queda

${ }^{14}$ El deterioro se produce en los diversos componentes, es decir, en las telas de soporte, entretelas y forros, así como en los bordados. Las telas pueden presentar desgaste, pliegues o arrugas, rasgaduras, faltantes producto del ataque biológico (por polillas), suciedad, adherencias de materiales extraños (cera de las velas y cirios) y manchas diversas, entre otros. Mientras que los bordados generalmente se enganchan por la parte de adelante, presentan áreas faltantes, hilos sueltos, desprendimiento de cordones, y pérdida de elementos como lentejuelas y pedrería, etc.

15 Ágreda Pino menciona que esta técnica comenzó a usarse desde el siglo XVIII (ÁGreDA PINO 1998: 387). Esta práctica continúa en la actualidad. 
registro gráfico ni memoria escrita sobre estas intervenciones realizadas, salvo algunas fotografías de trabajos muy recientes.

\section{COLORES}

La variedad de colores en la liturgia cristiana surgió de la tradición popular y fue reforzada por las tendencias místicas y simbólicas de la Edad Media. Los colores de los ornamentos litúrgicos fueron elegidos en relación con el carácter del día, o de la función sagrada a celebrar, con el objetivo esencial ayudar a los fieles a distinguirlos con la mayor claridad posible, saber de antemano de qué color estaría vestido el ministro que oficiaría la misa fieles y a entender el misterio que se celebra en la misa.

Actualmente son seis colores admitidos por el ritual romano en su liturgia: blanco, rojo, verde, morado, rosado y negro. Los colores azul y amarillo que tanto fueron usados en la Edad Media, están prohibidos actualmente. Sin embargo, el color azul está concedido a España en la fiesta de la Inmaculada Concepción de María, en su Octava y el las misas votivas de la misma. ${ }^{16}$

El brocado de oro, por su sentido de riqueza y solemnidad, podía reemplazar a los otros colores con excepción del negro y el morado, mientras que el brocado de plata y el lamé podían sustituir al blanco y al azul celeste.

\section{Tres CASUllas SELECtas}

\section{Casulla roja de raso de seda, colección de la Basílica Catedral de Lima}

De la colección de ornamentos litúrgicos de la Basílica Catedral de Lima se ha seleccionado una casulla de raso de seda de color rojo, del siglo XVII, que forma parte de un terno del cual han llegado hasta nosotros, también una capa pluvial, un manípulo y un cubre-corporal. La superficie del conjunto está bordada con hilos entorchados de oro y plata con motivos vegetales que se combinan de manera armoniosa. El contorno de las piezas, con excepción del manípulo, va señalado con una banda de motivos vegetales formando pequeños roleos con florecillas de cinco pétalos, y el perímetro está rematado con un galón muy delgado. Las prendas están cubiertas por abundantes motivos bordados, presentan aplicaciones de lentejuelas de pequeñas dimensiones.

${ }^{16}$ Enciclopedia de la Religión Católica V 1953: 1077. 
La casulla ${ }^{17}$ tiene forma de guitarra y es redondeada en la parte inferior. La sección de la espalda tiene lados rectos, y se ensancha ligeramente hacia la parte de abajo; mientras que en la sección delantera presenta escotaduras muy marcadas en la mitad superior, y la parte inferior se abre a manera de trapecio. Ostenta, tanto en la delantera como en la espalda, motivos de origen vegetal distribuidos de manera simétrica a los lados del eje central. Cada cara posee las mismas características, pero se diferencian por la decoración en el tercio superior. Las clavi que enmarcan la columna están formadas por una banda de hojas de tres puntas que se mueven suavemente hacia la izquierda y la derecha, y se alternan con espigas.

La pieza ha sido realizada en la técnica de bordado de realce con hilos dorados, sobre un relleno o alma de algodón. Los hilos de oro se han fijado a la tela de base mediante pequeñas puntadas de seda. También presenta aplicaciones de cabujones, lentejuelas pequeñas, gemas de cristal y lleva cordoncillo para delinear los diseños y destacar los detalles. Los motivos predominantes en la casulla son de origen vegetal, como en todo el conjunto.

En la parte inferior de la columna hay una flor de lis compuesta por tres hojas de acanto dispuestas en abanico, que está apoyada en un conjunto de hojas pequeñas que se dirige hacia abajo. De su centro nacen tres apéndices, los laterales tienen hojas que se enroscan, y el central es una palmeta frontal. En el primer tercio los apéndices se cierran sobre la palmeta. El segundo se inicia con un tallo de cardo flanqueado por dos flores ${ }^{18}$, que termina en un conjunto de siete hojas de acanto que da origen a dos hojas de laurel que se separan, curvándose suavemente, lo que resulta en el último tercio que diferencia ambas caras de la casulla [fig. 14].

En la espalda, sobre las hojas de laurel, se encuentra la imagen de una paloma con las alas desplegadas, su cabeza está hacia abajo y se dirige hacia la derecha. Está rodeada por diez resplandores, formados cada uno por cinco rayos dorados, el central es de mayores dimensiones que los laterales, todos terminados en punta de corte oblicuo en señal de reverberación. En la delantera, sobre las hojas de laurel se repite el motivo del cardo, flanqueado por racimos de uvas y coronado por una flor campaniforme.

En ambas caras, a los lados de la columna, hojas de acanto de perfil forman grandes roleos rematados con coronas de laurel y flores. Los roleos, que nacen de una flor de lis compuesta por tres hojas de acanto dispuestas en abanico que se encuentra en la parte inferior, se distribuyen a todo lo largo hasta llegar a los hombros en la espalda, en la delantera se interrumpen a la altura

\footnotetext{
${ }^{17}$ Dimensiones: 104 x $66 \mathrm{~cm}$.

18 Podría tratarse de girasoles. Estas flores buscan la luz del sol por lo que su núcleo se asocia a la fe.
} 
del tercio superior. Llenan el espacio las hojas de vid, racimos de uvas y espigas [fig. 15].
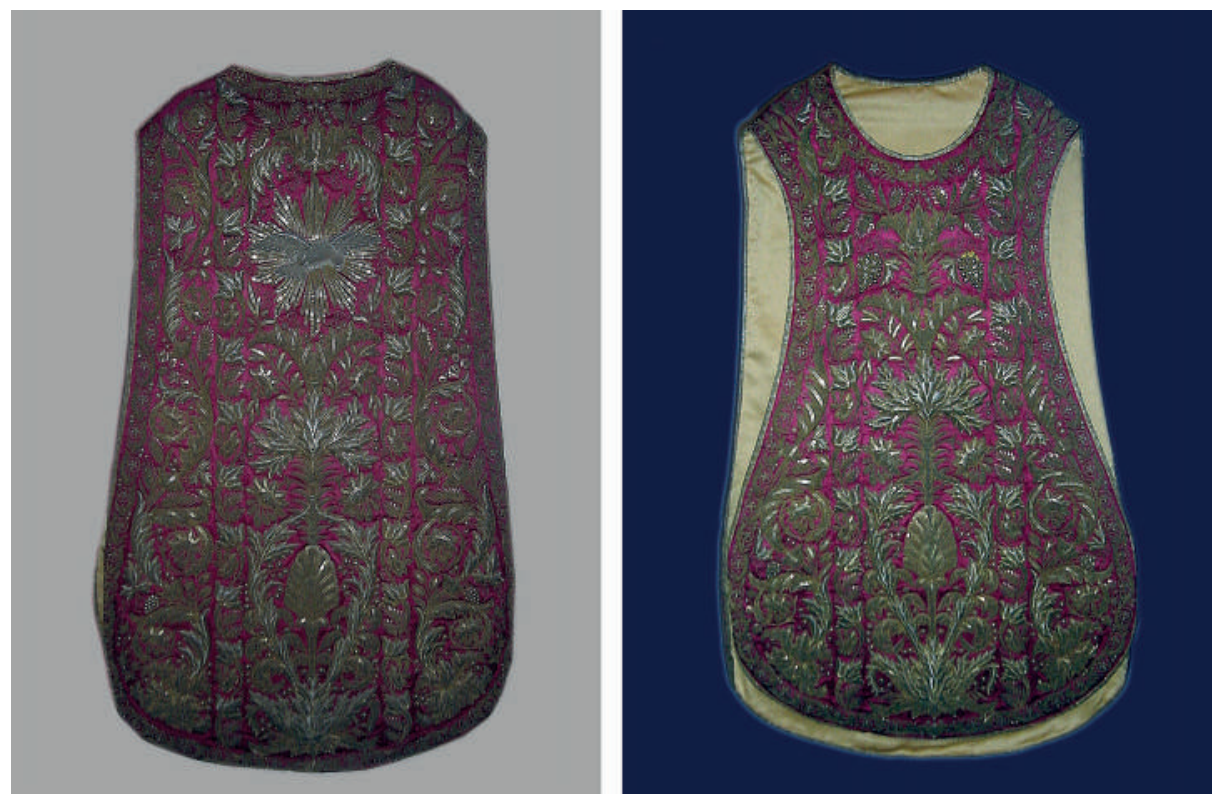

Fig. 14. Casulla roja de raso de seda. Siglo XVII, espalda y sección delantera. Basílica Catedral de Lima (fot. Patricia Victorio)

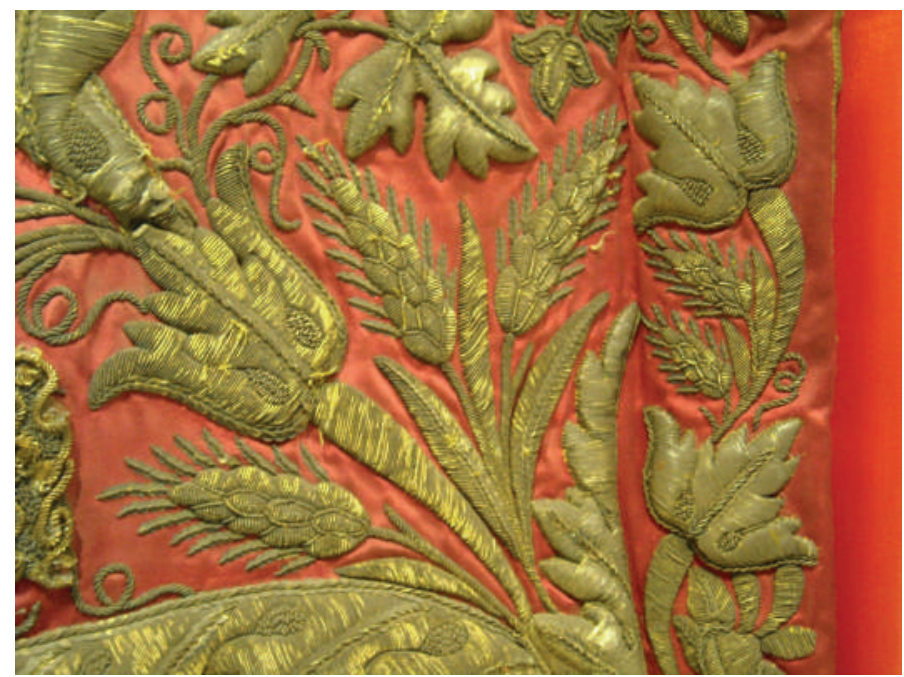

Fig. 15. Espigas. Casulla roja de raso de seda. Siglo XVII. Basílica Catedral de Lima. Detalle (fot. Marcela Ramírez) 
El despliegue de motivos en la casulla provoca la sensación de horror vacui. En el tercio superior de la espalda, el movimiento ondulante de los motivos vegetales de la columna asciende para circundar a la paloma del Espíritu Santo, plateada y rodeada de resplandores. Su posición, con las alas desplegadas y la cabeza hacia abajo, alude a un "rompimiento de gloria", que destaca sobre el rojo del fondo por el contraste de los materiales y la técnica de ejecución. En la sección delantera los roleos laterales comportan un sentido ascensional, que va decreciendo proporcionalmente hasta desaparecer al llegar al tercio superior.

El volumen del relieve de los motivos juega un rol importante en el efecto general. Los materiales con los que se han realizado los bordados y las diferentes calidades de hilos de oro y plata, así como las lentejuelas y cabujones que se alternan en armonía, refuerzan estas apreciaciones. El sutil brillo de seda roja, sumado a la profusión de motivos, el relieve y textura de los bordados y las aplicaciones en oro y plata en la prenda provoca un notable efecto en el espectador. Asimismo, los contrastes de luces y sombras que se producen por la incidencia de la luz incrementan la sensación de magnificencia.

El simbolismo de la casulla descrita se refiere al sacrificio de Cristo, a la redención, y perpetúa la institución del sacramento de la Eucaristía; su mensaje es, entonces, eucarístico y Cristológico. Los motivos: las hojas de vid, las uvas y las espigas, aluden directamente a la Eucaristía ${ }^{19}$ y al episodio de la Última Cena. La espiga está relacionada con el pan y simboliza la carne de Cristo, también representa la vida sacerdotal. Las hojas de vid, junto con el racimo de uvas, aluden al vino que simboliza la sangre de Cristo. ${ }^{20}$ Las hojas de acanto señalan la inmortalidad del alma y sus espinas simbolizan dolor y penitencia, en clara alusión a la Pasión de Cristo, al sacrificio de Nuestro Señor y la redención. Todo ello se ve reforzado por el color rojo del soporte, usado especialmente para la celebración de la Pasión. La paloma representa al Espíritu Santo en la casulla, volando sobre lo alto en rompimiento de gloria; también alude al alma inocente blanqueada por la penitencia o purificada por la muerte. ${ }^{21}$

\section{Casulla Mariana, colección del Convento de San Francisco}

Una de las piezas más interesantes de la colección del Convento de San Francisco es, sin lugar a dudas, la denominada Casulla Mariana ${ }^{22}$ de inicios del siglo

${ }_{19}$ Esta interpretación se amplía gracias a la afirmación de Esteban Lorente respecto a que "La vid [...] se convierte así no sólo en simbolismo eucarístico sino en la propia persona de Cristo, en el árbol de la vida del cristiano [...] Las espigas como antecedentes del pan será un mensaje frecuentemente usado..." EsteBAn LORENTE 1995: 236.

20 Armella de Aspe 2007: 50.

21 RÉAU 2000: 101.

22 Dimensiones: $100 \times 62 \mathrm{~cm}$. 
XIX. Ha sido confeccionada en raso blanco de seda y presenta la característica forma de guitarra. La sección de la espalda insinúa, en la parte superior, una concavidad a la altura de los brazos y se ensancha hacia la parte inferior, mientras que la sección delantera presenta escotaduras marcadas en la mitad superior, y la parte inferior se expande y adquiere forma redondeada.

Toda la superficie de la prenda está decorada con bordado sobrepuesto de realce y "pintada a la aguja" (fig. 11). El bordado de realce está ejecutado en soporte rígido de cartón, con hilos entorchados de plata y oro, y los detalles están delineados con cordoncillo de los mismos materiales. Muestra, tanto en la sección delantera como en la espalda, motivos de origen vegetal, en especial flores, distribuidos de manera simétrica a los lados del eje central, realizados con hilos de seda de colores. Cada cara posee las mismas características, pero se diferencian por la decoración en el remate del tercio superior. Las clavi que enmarcan la columna, así como el galón de contorno, están formadas por una banda con un motivo de realce que se repite una y otra vez. Se trata de un rombo que remata, en la parte superior, en dos ramas cruzadas que se abren para dar inicio al siguiente motivo [fig. 16].
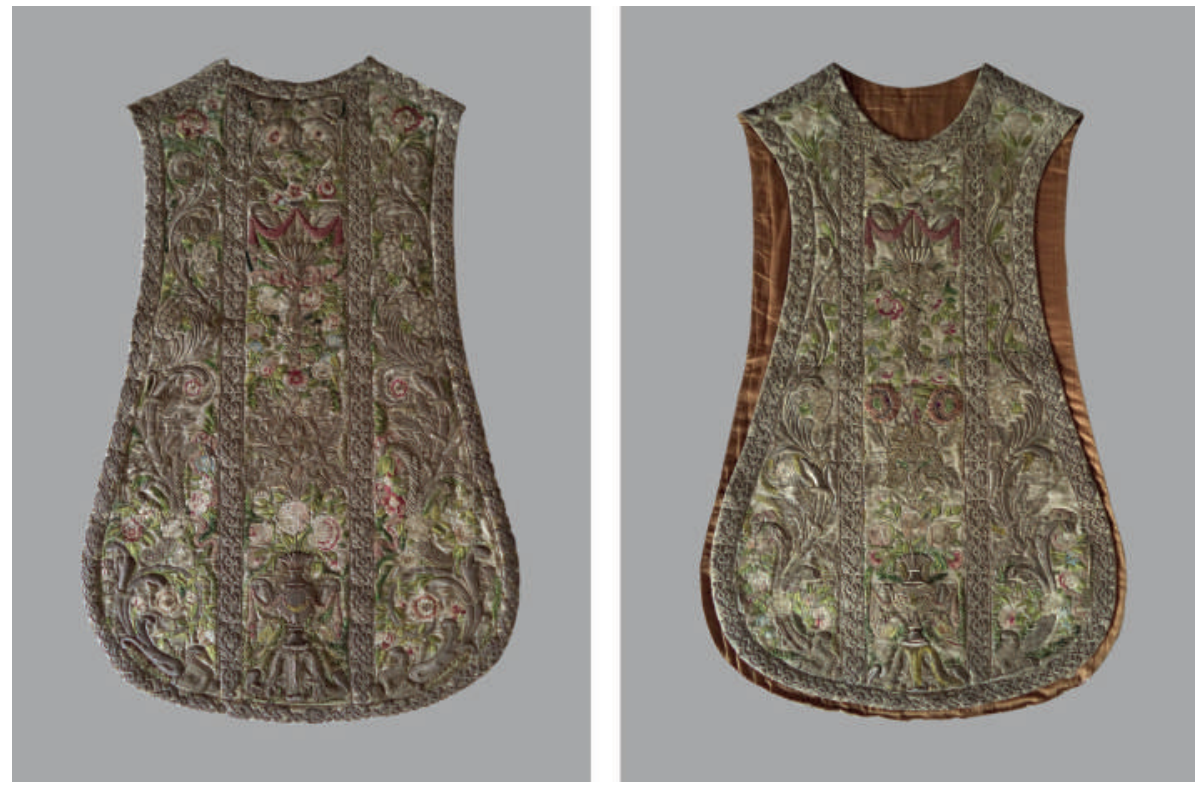

Fig. 16. Casulla Mariana. Inicios del siglo XIX, espalda, sección delantera. Convento de San Francisco (fot. Patricia Victorio)

En el tercio inferior de la columna de ambas caras, señalando el eje de la composición, un recipiente se eleva sobre una base trípode formada por tres 
hojas de acanto invertidas. El perfil del recipiente recuerda las ánforas griegas, pero sus detalles han sido reemplazados por hojas, sus asas laterales se extienden a los lados y se enroscan, de sus extremos pende una banda drapeada que continúa como una guirnalda, de las mismas características, cruza delante del cuerpo y se sostiene en dos puntos para formar tres colgaduras. De su boca emanan tallos con hojas, que terminan en rosas y claveles de colores. El segundo tercio se inicia con un lazo que ata un ramo de flores de colores del que brota un tallo recto y vertical, en el eje que marca la simetría de la composición y, a la vez, da origen al recipiente que ocupa el tercio superior, cuya forma repite el perfil griego mediante la unión de tres hojas de acanto. El recipiente care-

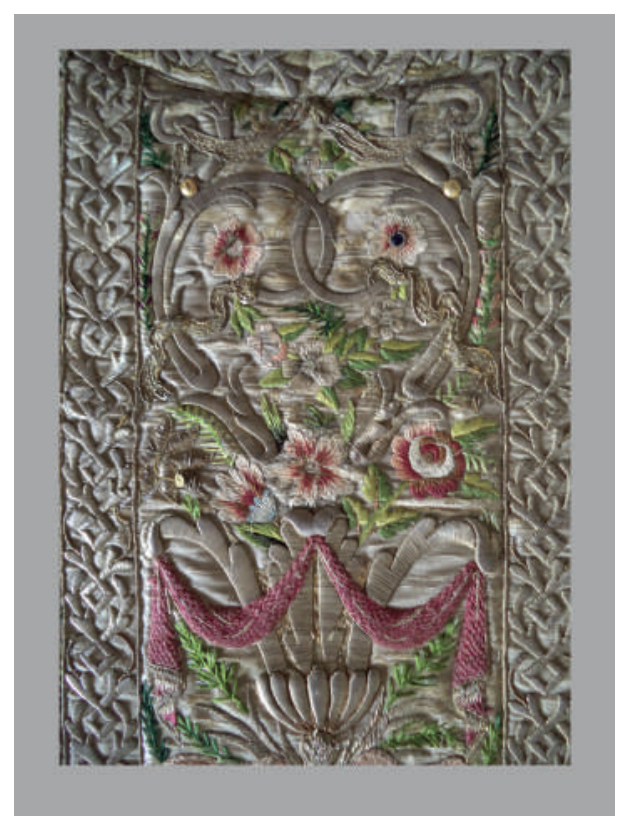
ce de asas, sin embargo, las hojas laterales se abren hacia el exterior y de sus extremos pende una banda drapeada que continúa como una guirnalda, cruza delante del cuerpo y se sostiene en un punto para formar dos colgaduras, de su boca emanan flores de colores. Solo en la sección de espalda nacen dos tallos con espinas se enroscan, uno frente al otro, para componer una forma acorazonada [fig. 17].

Fig. 17. Casulla Mariana. Forma acorazonada. Inicios del siglo XIX. Detalle. Convento de San Francisco (fot. Patricia Victorio)

En las dos caras, a los lados de la columna, abundan los motivos vegetales, hojas de acanto de perfil que forman roleos, palmas y tallos rematados con hojas de laurel y flores de colores. Los roleos nacen de un cáliz que se encuentra en la parte inferior, ascienden acompañados de espigas que rematan en hojas de palma, flores y racimos de uvas. En la sección delantera, la secuencia se interrumpe hacia la mitad, y se desarrollan tallos que presentan formas ondulantes, y hojas que llenas el espacio que se estrecha debido a las escotaduras para los brazos.

El simbolismo de esta casulla es Mariano, Cristológico y Eucarístico, identifica a María como Mater Dei, y custodia del Verbo, expresado mediante la presencia del ánfora que cumple el rol del jarrón. Las flores aluden a la Virgen, 
que en las escrituras se le llama "Rosa de Sarón", ${ }^{23}$ y en las Letanías Lauretanas "Rosa Mística". Igualmente, se relacionan con las Virtudes Marianas, identificadas con la perfección, la belleza física y espiritual de María. La rosa también sugiere la sangre y el sacrificio de Cristo, y la presencia de las ramas con espinas recuerdan la corona que ciñó Su frente durante la Pasión.

La espiga es el símbolo eucarístico, está asociada con el pan que representa la carne de Cristo que muere para dar vida al mundo, es decir, el pan de vida; la espiga es también símbolo de la vida sacerdotal, expresada en la Eucaristía, fuente de comunión eclesial. El racimo de uvas hace referencia directa a la $\mathrm{Pa}-$ sión de Cristo y al episodio de la Última Cena, simboliza la sangre de Cristo. Finalmente, el blanco del soporte refleja la luz, y está relacionado con "los Misterios Gozosos y Gloriosos del Señor". ${ }^{24}$ Su uso se recomienda en Pascua de Resurrección, Navidad y Epifanía, Jueves Santo, en las fiestas de Nuestro Señor, la Virgen, los ángeles y los santos que no son mártires, misas de Confirmación, Bautismo y Matrimonio.

La Casulla Mariana muestra una profusa pero bien organizada decoración - que prácticamente oculta el soporte - realizada en base a flores, racimos de uvas, hojas de acanto, espigas, entre otros motivos de origen vegetal de contenido simbólico. Los detalles se han multiplicado, la repetición de motivos, la variedad de texturas, y el gusto por la simetría imprimen un efecto armonioso y equilibrado. El despliegue de motivos en la casulla no llega a provocar la sensación de horror vacui, la decoración está ordenada en el espacio de manera coherente y se concentra especialmente en la columna, que recorre en sentido vertical la sección de la espalda así como la delantera, mientras que los roleos laterales comportan un sentido ascensional. La columna, enmarcada por las clavi, está bien definida y destaca plenamente. Los materiales con los que se ha realizado los bordados, en los que se ha combinado diferentes calidades de hilos de plata y oro, que resplandecen por el juego de luz y sombra, y la presencia de los hilos de seda de colores refuerzan estas apreciaciones.

Se ha aprovechado el contraste de texturas y matices, y se ha tomado en cuenta la aplicación y correspondencia de las puntadas con la incidencia de la luz para generar un impacto visual y simbólico. La luz juega un papel protagónico, es el elemento que resalta los ornamentos litúrgicos en general y a esta casulla en particular. El brillo natural de la seda y la reflexión de la luz sobre los hilos de oro y plata, y sobre los hilos de colores contribuyen al efecto de conjunto, especialmente cuando el oficiante, revestido con esta prenda, realiza la ceremonia.

23 Armella de Aspe 2007: 58.

${ }^{24}$ SCHENONE 1992: 808. 


\section{Casulla morada de muaré de seda del Monasterio de Nazarenas Carmeli- tas Descalzas}

La casulla seleccionada integra un terno compuesto también por dos dalmáticas, una estola, un manípulo, y el capillo de una capa pluvial, está fechado hacia mediados del siglo XX. El conjunto ha sido confeccionado en muaré de seda, cada prenda ostenta una ornamentación bien organizada en cenefas con estructura de carácter romboidal y motivos de origen vegetal como flores y roleos [fig. 12]. Las prendas se vinculan entre sí por una serie de elementos comunes, entre los que destaca la presencia de motivos vegetales que se repiten con regularidad, enmarcados en espacios geométricos claramente delimitados en la cenefa que proporciona al conjunto una sensación de dinamismo ordenado.

La casulla ${ }^{25}$ morada presenta la espalda de lados rectos, una cruz latina ocupa todo el campo, la columna forma el segmento vertical (stipes), mientras que el elemento horizontal (patibulum) queda a la altura de los brazos, al centro destaca el monograma de Cristo o IHS en caracteres góticos, enmarcado en un octógono lobulado. La sección delantera es de contorno redondeado y tiene la característica columna central [fig. 18].
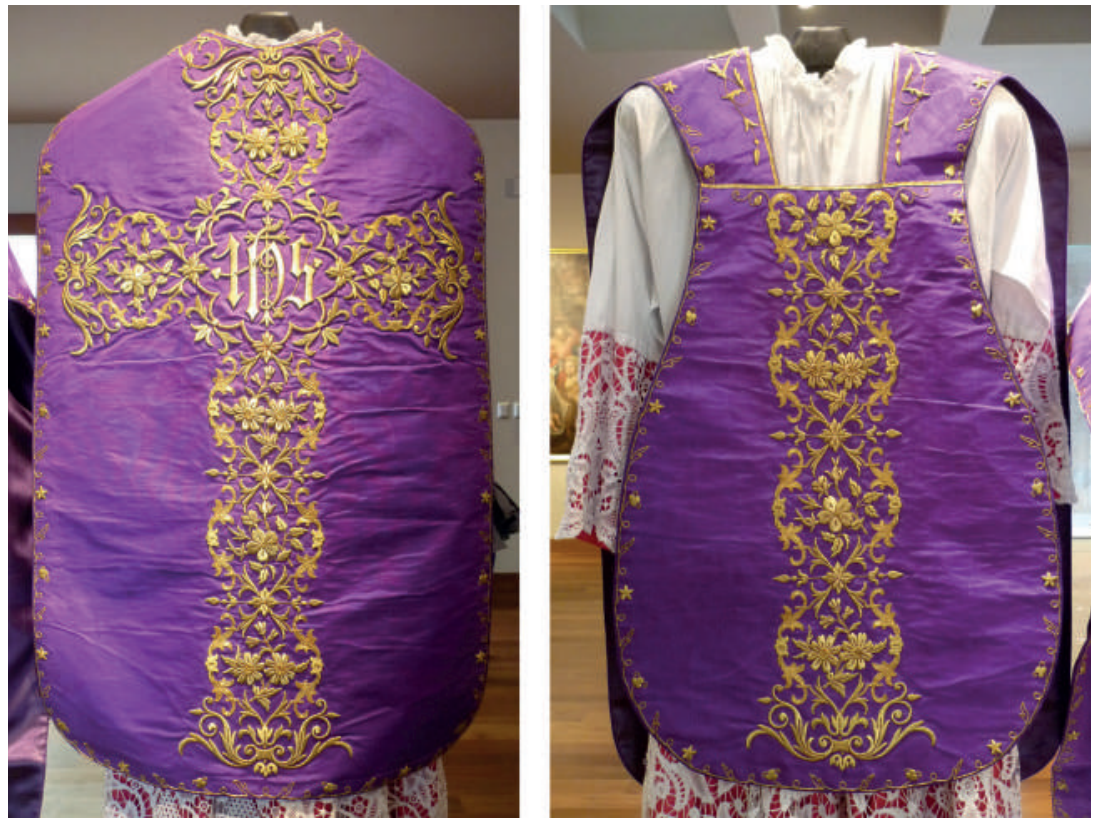

Fig. 18. Casulla morada de muaré. Mediados del siglo XX, espalda, sección delantera. Colección: Monasterio de Nazarenas Carmelitas Descalzas (fot. Patricia Victorio).

${ }^{25}$ Dimensiones: 105 x $69 \mathrm{~cm}$. 
No presenta galón alrededor sino más bien decoración de carácter cursivo y tréboles. El bordado ha sido ejecutado con hilos de oro, en tres técnicas que contrastan texturas, la primera es el matizado, en el que los hilos metálicos se han colocado en sentido horizontal sobre el tejido, y se han fijado con hilos de seda de color anaranjado, el motivo queda plano. La otra es el bordado de realce, en el que los hilos de metal se han enrollado sobre un soporte rígido, con la forma deseada y luego se ha fijado al soporte con puntadas alrededor. Finalmente, han sido delineados mediante un cordoncillo dorado fijo al soporte con hilo de seda, mediante puntadas visibles.

El discurso iconográfico de la casulla es Mariológico y Cristológico y apunta a la salvación manifestada por la presencia de la cruz para simbolizar el sacrificio de Cristo. Las flores están asociadas con la Virgen como ya se ha mencionado antes. En tanto que el $I H S$ corresponde al monograma de Cristo formado por la primera, segunda y la última letra del nombre de Jesús en griego IHSUS o IHCUC, y corresponde a las letras griegas iota, I: i latina; eta, que se escribe en mayúscula $\mathrm{H}$; y sigma $\mathrm{S}$. Se presenta inscrito en un octógono, figura geométrica que alude a la vida eterna puesto que el número ocho se asocia con la Pasión y Resurrección de Nuestro Señor, y simboliza a la vez la promesa de resurrección del hombre transfigurado por la gracia [fig. 19].

Fig. 19. Casulla morada de muaré. Detalle: monograma de Cristo. Colección: Monasterio de Nazarenas Carmelitas Descalzas (fot. Patricia Victorio)

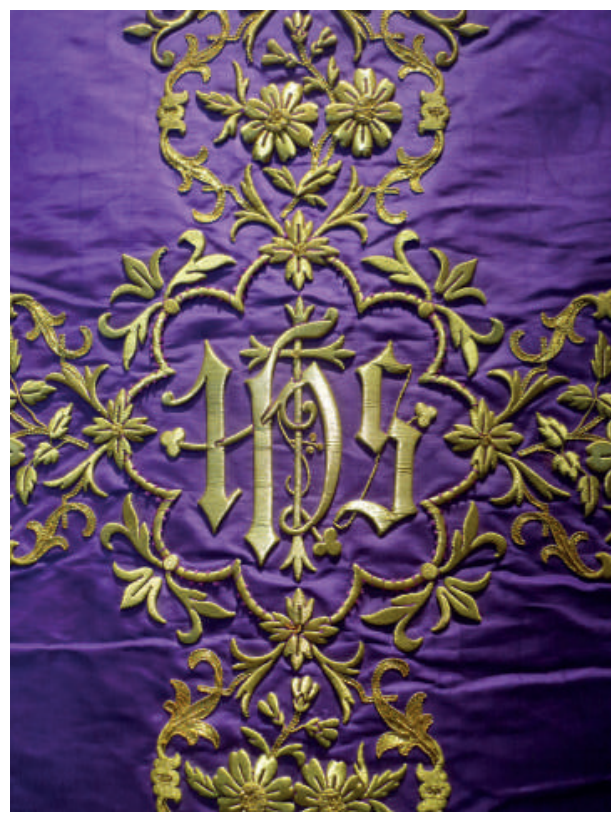

El contraste entre los motivos bordados en oro y el fondo brillante y con las marcas propias del soporte es sobrio, armónico y refleja la suntuosidad del terno, en el que predomina lo ornamental. Las técnicas del bordado incrementan el contraste debido a que los motivos destacan del soporte por su relieve y textura. 
El color morado fue considerado intermedio entre el rojo y el negro y calificado como afín a este último. Es usado en las celebraciones de Adviento y también en Cuaresma, tiempo de penitencia, extremaunción y renovación; también en funerales y misas de difunto. Significa: penitencia, oración, abstinencia, humildad, retiro, profundización espiritual, y ayuda a recordar que la preparación para la venida de Cristo.

\section{COMENTARIOS FINALES}

Como se advierte, las casullas presentadas dan luces sobre la importancia de las colecciones de ornamentos litúrgicos de la ciudad de Lima, capital del Reino del Perú durante el virreinato. En ellas destaca la suntuosidad y la tendencia hacia lo decorativo que se expresa en la riqueza de los materiales empleados, así como la presencia de los diversos tipos de bordados que se conjugan armónicamente a fin de enfatizar el contenido simbólico. La luz juega un papel protagónico, es el elemento que resalta los ornamentos litúrgicos. El brillo natural de la seda y la reflexión de la luz sobre los hilos de oro y plata, las lentejuelas y gemas de cristal de colores contribuyen al efecto general.

El programa iconográfico está ligado a los misterios Cristológico, Eucarístico y Mariológico, acompañado por un repertorio de motivos de origen vegetal en el que destacan espigas, racimos de uvas, hojas de vid y pámpanos así como diversas flores. El significado se refuerza debido a la existencia de pautas precisas sobre los temas y el uso de colores asociados con el calendario cristiano, En este programa iconográfico, desarrollado con gran habilidad por los artífices de la aguja, ningún elemento está colocado al azar, más bien concentra un mensaje específico en apoyo al sermón y sustentado en la tradición.

\section{Bibliografía}

Ágreda Pino 1998 - A.M. Ágreda Pino “Aportaciones al estudio del patrimonio artístico textil en Aragón. Los ornamentos de la catedral de San Salvador de Zaragoza". Artigrama, N 13: 383-395, 1998. Recuperado de: http:/www.unizar.es/artigrama/pdf/13/4patrimonio/3.pdf Armella De Aspe 2007 - V. Armella de Aspe, Hilos del cielo. Las vestiduras litúrgicas de la Catedral Metropolitana de México. México: Instituto Nacional de Antropología e Historia, 2007. 
Clavijo et al. 2000 - M. Clavijo, A. Ovalle, M. Rodríguez y C. Villalobos, "Tecnología de la colección". Cuadernos de taller. $N^{\circ} 1$ Textiles. Bogotá: Facultad de Restauración de Bienes Muebles, Universidad Externado de Colombia (pp. 24-29), 2000.

Enciclopedia de la Religión Católica 1953 - Enciclopedia de la Religión Católica. Tomos I a VII. Barcelona: Dalmau y Jover S. A. Ediciones, 1951-1956.

EstebAn LORENTE 1995 - J.F. Esteban Lorente Tratado de iconografía. Madrid: Ediciones Istmo S. A., 1995.

Floriano Cumbreño 1942 - A. Floriano Cumbreño, El Bordado. Barcelona: Editorial Alberto Martín, 1942.

LOBERA y ABio 1846 - A. Lobera y Abio, El por qué de todas las ceremonias de la Iglesia y sus misterios. Cartilla de prelados y sacerdotes que enseña las ordenanzas eclesiásticas que deben saber todos los ministros de Dios, y en forma de diálogo simbólico entre un vicario instruido y un estudiante curioso. Paris: Editor A. Mezin, 1846.

Misal Romano - Misal Romano, Capítulo I. Importancia y dignidad de la Celebración Recuperado de: http://vicariadepastoral.org.mx/liturgica/estudio_liturgico/igmr.pdf.

Plazaola 1965 - J. Plazaola, "Los Utensilios Litúrgicos". En: El Arte Sacro actual. Estudio. Panorama. Documentos. Madrid: Editorial Católica (pp 460-499), 1965.

RÉAU 2000 - L. Réau, Iconografía del arte cristiano. 2 tomos, 5 volúmenes, e Introducción General. Barcelona: Ediciones del Serbal, [1957] 1997-2000.

RighetTi 1955 - M. Righetti, Historia de la Liturgia. Introducción general. Año Litúrgico. El Breviario. Tomo: I. Madrid: Editorial Católica, 1955.

Romero Ortega 1989 - F. Romero Ortega, "La manga bordada del Corpus de la Catedral de Toledo", Arte, individuo y sociedad, N², pp. 107-145, 1989. Recuperado de: https://dialnet.unirioja.es/servlet/articulo?codigo $=157934$

Schenone 1992 - H. Schenone, Iconografía del Arte Colonial. Los Santos. 2 volúmenes, Buenos Aires: Fundación Tarea, 1992.

Sigüenza Pelarda 2006 - C. Sigüenza Pelarda, "Los ornamentos sagrados en la Rioja. El arte del bordado durante la Edad Moderna". Berceo, $\mathrm{N}^{\circ} 150$, pp. 189-230, 2006. Recuperado de: https://dialnet.unirioja.es/ descarga/articulo/2229456.pdf

Staniland 2000 - K. Staniland. Bordadores. Artesanos medievales. Madrid: Ediciones Akal, 2000. 
Victorio Cánovas 2015 - E. P. Victorio Cánovas, Seda y oro para la gloria de Dios. Los ornamentos litúrgicos de la Basílica Catedral de Lima. Lima: Conferencia Episcopal Peruana, Comisión Episcopal de Liturgia del Perú y Museo de Arte Religioso de la Catedral de Lima, 2015.

\section{Summary \\ Piety and sumptuousness: the liturgical ornaments of three Lima collec- tions}

The purpose of this article is to contribute to the knowledge of liturgical ornaments in general, as well as to bring readers closer to understanding of the importance of the collections of the Cathedral Basilica of Lima, the San Francisco Convent and the Nazarenas Carmelitas Descalzas Monastery. These works not only present contents and particularities based on their symbolic character promoted by the Church, but also integrate plastic values of local origin.

Keywords: liturgical ornaments, silk, chasuble, textile art, peruvian art, embroidery

\section{Streszczenie}

\section{Pobożność i przepych: szaty liturgiczne z trzech kolekcji limeńskich}

Celem artykułu jest poszerzenie wiedzy ogólnej na temat ozdób liturgicznych, a także przybliżenie czytelnikom znaczenia zbiorów zgromadzonych w Bazylice Katedralnej, Klasztorze św. Franciszka i Klasztorze Karmelitanek Bosych (Nazarenas) w Limie. Dzieła te nie tylko prezentują treści istotne z punktu widzenia języka symbolicznego propagowanego przez Kościół, lecz także inkorporują walory estetyczne pochodzenia lokalnego.

Słowa kluczowe: szaty liturgiczne, jedwab, ornat, sztuka tekstylna, sztuka peruwiańska, haft 